\title{
Пятьдесят лет конкурсу на плато Бобур
}

\author{
Т.И.Возвышаева, НИИТИАГ, Москва
}

Ровно пятьдесят лет назад в 1969 году был проведён международный конкурс на проект культурного центра в Париже. Проект-победитель был весьма неоднозначно воспринят профессиональным сообществом, а построенное через несколько лет на плато Бобур сооружение произвело эффект эмоционального шока. Расценённый современниками как эпатажный эксперимент молодых архитекторов Р. Роджерса и Р. Пиано, Центр Помпиду по существу стал зданием-манифестом архитектуры хай-тек, положив начало значимому направлению в архитектуре последней трети XX века. В статье прослеживается история формирования концепций, положенных в основу этого проекта, показывается приверженность их авторов традициям модернизма в освоении феномена техники в архитектуре на новом этапе её технологического развития. Дистанция времени позволяет беспристрастно оценить значимость для развития современной архитектуры этого экстраординарного сооружения, ставшего со временем наиболее посещаемым местом столицы Франции.

Ключевые слова: Центр Помпиду, архитектура хай-тек, технические инновации в архитектуре, механоморфная эстетика, социальная значимость, поздний модернизм.

\section{Fifty Years of Competition for the Beaubourg Plateau}

\section{T.I.Vozvyshaeva, NIITIAG, Moscow}

Exactly fifty years ago, in 1969, an international competition was held for the design of a cultural center in Paris on the Beaubourg Plateau. The winning project was very ambiguously accepted by the professional community, and the construction built a few years later produced the effect of emotional shock. Appreciated by contemporaries as an epithetic experiment by young architects R. Rogers and R. Piano, the Pompidou Center essentially became a manifesto of high-tech architecture, laying the foundation for a significant trend in architecture of thelast third of the 20th century. The article traces the history of the formation of the concepts underlying this project, shows the continuity of the traditions of modernism in the mastering the technology phenomenon in architecture at a new stage of its development. The distance of time allows to impartially assess the significance architectural process of this extraordinary structure for the world which has become over time one of the most attractiv place in the capital of France.

Keywords: Pompidou Center, high-tech architecture, technical innovations in architecture, mechanomorphic aesthetics, social significance, late modernism.
Полвека отделяет 2019 год от 1969-го, когда, только что став президентом Франции, Жорж Помпиду принял решение о проведении международного конкурса для строительства в центре Парижа на плато Бобур многопрофильного культурного центра. Этот конкурс привлёк к себе огромное внимание профессионального сообщества сначала своей масштабностью и значимостью места, а после подведения итогов - неожиданностью выбора жюри наиболее радикального для своего времени проекта. Возникшее спустя несколько лет в центре мировой столицы искусств сооружение получило имя своего патроната - «Центр Помпиду», и успешно функционирует уже более сорока лет (рис. 1). С позиции сегодняшнего дня можно более объективно оценить мотивы и закономерности появления сначала проекта, а через два года - и экстраординарного сооружения, выявить все плюсы и минусы, а также обозначить его значимость для развития современной архитектуры.

Хорошо известно, насколько негативно Центр Помпиду был воспринят как горожанами, так и профессиональным сообществом. Критики называли его нефтеперегонным заводом и «наглым творение архитектурных хиппи». Сами авторы, которым к тому времени не было и сорока лет - англичанин Ричард Роджерс и итальянец Ренцо Пиано, оглядываясь назад, говорят о том, что такую шокирующе бескомпромиссную архитектуру могли сделать только очень молодые и отчаянные люди, живущие в эпоху тотального свержения канонов и правил.

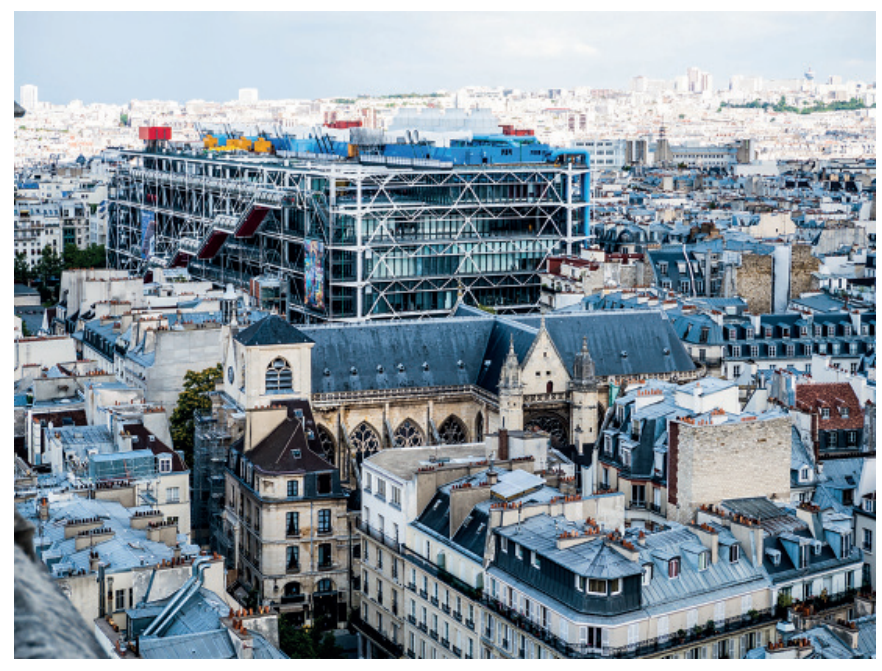

Рис. 1. Здание Центра Помпиду. Вид на плато Бобур. Фото Яна Кардека 
Сегодня очевиден факт постоянного притяжения миллионов посетителей и туристов к этому сооружению, ставшему, наряду с Эйфелевой башней, знаковым местом Парижа. Появившись в нужное время в нужном месте, здание Центра Помпиду заявило о себе громко и убедительно. Однако в его появлении существенную роль сыграло множество как предопределённостей, так удивительных стечений обстоятельств.

Конец 1960-х годов в Европе было временем бурного всплеска протестных молодёжных движений и активных выступлений «левых сил» за социальную справедливость. В значительной мере они были связаны с ожиданиями существенных демократических преобразований в процессе перехода от индустриального к постиндустриальному обществу. Результаты развёртывающейся на глазах научно-технической революции должны были, как представлялось, освободить рядового человека от тяжёлого труда и открыть для него широкие возможности для творческого развития.

В 1969 году президентом Франции стал Жорж Помпиду литературовед по профессии и ценитель искусств по призванию. За год до этого, в 1968 году, когда Франция была охвачена студенческими волнениями и забастовками профсоюзов, он, будучи ещё главой правительства, сыграл решающую роль в проведении переговоров и подписании соглашений, которые положили конец так называемой «майской революции» во Франции. Став президентом, главной задачей своей политики он избрал примирение и успокоение страны. С его именем связаны также самые важные процессы в области технической модернизации того времени и такие архитектурные новации, изменившие облик и силуэт Парижа, как башня «Монпарнас» и высотный деловой квартал Дефанс.

В том же 1969 году по его инициативе был организован международный конкурс на проект многопрофильного культурного центра в самом центре Парижа на плато Бобур - территории с большим пустырём, граничащей с местом, известным как Чрево Парижа, с плотной исторической застройкой, Центральным рынком и крупным транспортно-пересадочным узлом регионального метро.

К концу 1960-х годов район Бобур превратился в один из самых депрессивных и криминальных районов французской столицы, который требовал реконструкции. Месту, выбранному молодёжью для своих выступлений, необходимо было придать новое качество.

Какова была концепция и цели конкурса? В здании нового Центра необходимо было предусмотреть более вместительные помещения для существующего Музея современного искусства, а также площади для вновь создававшегося по инициативе композитора Пьера Булеза Центра современной музыки. Но главное, в нём предполагалось организовать новый для Центра современного искусства вид деятельности, для которого были необходимы помещения для периодических выставок и публичной библиотеки, а также кинозалов, кафе и ресторанов. Кроме того, для организации разных видов активной деятельности в Центре планировалось созда- ние открытых пространств с возможной трансформацией их в соответствии с меняющимися запросами времени

Для реализации проекта здания, которое задумывалось устроителями конкурса ни больше, ни меньше, как сооружение, не похожее ни на что существующее прежде в архитектуре, были выделены колоссальные средства, а участникам конкурса предоставлялись неограниченные возможности для творчества.

Такие привлекательные для каждого архитектора условия конкурса собрали участников из 49 стран, которые предоставили 681 проект. От СССР было прислано 30 проектов, а проект ГИПРОНИИ РАН стал лауреатом, получив положительные отзывы жюри.

Конкурс на плато Бобур по существу стал грандиозным форумом передовых архитектурных идей. В этих проектах прочитывались два принципиальных подхода: создание традиционного замкнутого объёма здания - хранилища произведений искусства, и современный для того времени подход - организация открытого и легко приспосабливающегося для быстро меняющихся потребностей пространства.

В состав жюри входили наиболее яркие представители архитектурной профессии того времени - автор Сиднейской оперы датчанин Йорн Утзон, американец Филипп Джонсон, бразилец Оскар Нимейер, а также известные писатели, художники и общественные деятели. Возглавил жюри француз Жан Пруве - автор Народного дома в Клиши, известный своими разработками сборных домов из стали и алюминия. Он был знаком с первыми постройками Ричарда Роджерса, которые к тому времени были отмечены критикой и получили премии за оригинальные решения сооружений из готовых металлоконструкций.

Таковым было здание фабрики электронного оборудования «Рилайенс Контролс» в Суиндоне (совместная работа Ричарда Роджерса, Нормана Фостера и инженера Энтони Ханта. 1967). Это здание-контейнер было собрано на месте за короткий срок из готовых металлических компонентов, имело очень низкую конечную стоимость, но вместе с тем за счёт мастерски проработанных деталей воспринималось в качестве архитектурного сооружения. В нём впервые были опробованы принципы совместной работы архитектора и инженера, принцип вынесения элементов технологического оснащения за пределы объёма и обеспечивалась возможность дальнейшего развития и трансформации. В соответствии с веянием времени принципиальным для авторов было обеспечение демократичного пространства с отсутствием иерархии рабочих и служебных помещений. Примечательно, что все эти принципы в качестве приоритетных сохранили в своей дальнейшей работе и Роджерс, и Фостер.

Внимание профессиональной критики также привлёк жилой дом, спроектированный Роджерсом для своих родителей и собранный в Уимблдоне из алюминиевых рам-сэндвичей, предназначенных для траков-рефрижераторов. Он был представлен на Парижской Биеннале в 1969 году в качестве репрезентации достижений британской архитектуры. 
Именно Пруве, который понимал, какие перспективы для архитектуры открывает применение инновационных строительных методов и материалов, удалось склонить жюри к выбору победителей, которых почти никто не знал. В то же время надо отдать должное и маститым архитекторам, принявшим такое непростое решение, их способности мыслить категориями будущего. Интересно, что, когда победивший проект показали Жоржу Помпиду, он, по свидетельству очевидцев, был от увиденного в шоке, но эта реакция никак не повлияла на принятое профессионалами решение.

Роджерс изначально не склонен был участвовать в конкурсе, поскольку без энтузиазма относился к идее создания здания-монумента, ассоциирующегося с фигурой одного человека - президента Франции. Сделать это его уговорил Тэд Хепполд - инженер крупнейшей британской инженерностроительной компании «0ве Аруп энд партнёрс». Мировую известность ему принесла оригинальная разработка сложнейшей конструктивной системы оболочек здания Сиднейской оперы, которая позволило осуществить архитектурный замысел Утзона и завершить долго тянущееся строительство. К этому времени Ричард Роджерс и Ренцо Пиано начали работать вместе, организовав компанию «Роджерс энд Пиано». Их объединяла общность взглядов на необходимость внедрения в архитектуру новых альтернативных методов проектирования, технологий и строительных материалов, способствующих, как они говорили, созданию «архитектуры для людей».

Для Роджерса всегда в приоритете была этическая и теоретическая стороны архитектурной профессии. Идеи современного движения о жизнестроительной роли архитектуры и социальной миссии архитектора воспринимались им очень серьёзно. Во многом его взгляды формировались под влиянием старшего двоюродного брата - архитектора Эрнесто Натана Роджерса - одного из авторов Манифеста итальянского футуризма, который до конца жизни оставался наиболее последовательным сторонником Современного движения в Италии. В его семье, члены которой придерживались лейбористских взглядов, всегда активно обсуждались темы справедливости общественного устройства. В престижной лондонской школе Архитектурной ассоциации, где учился Роджерс, студенты были увлечены русским архитектурным авангардом начала XX века, конструктивизмом, работами Леонидова и Чернихова. Позднее, во время учёбы в Йельском университете, Роджерса опекал и консультировал другой приверженец футуристического искусства - скульптор Наум Габо, известный как автор русского «Реалистического манифеста конструктивизма».

Свои взгляды на современную архитектуру Роджерс попытался выразить в двух своих манифестах 1969 года. В них он излагал своё отношение к «косной» системе архитектурного образования, закрытой для новых идей и технических возможностей, и призывал к созданию проектных мастерских, основанных на междисциплинарном взаимодействии профессионалов и широком их общении с потребителями и заказчиком. Он утверждал, что современные технологии способны в скором времени сделать работу и учёбу для человека намного более приятными и менее обременительными, чем прежде. В качестве решения экологических проблем он предлагал отказ от зданий в виде статичных монументов и переход к созданию трансформируемых, приспосабливающихся к меняющимся внешним условиям сооружений, которые при необходимости можно было бы быстро собрать и разобрать.

Пиано в этом содружестве удачно дополнял своего партнёра. Он вырос в семье потомственных строителей и на практике был хорошо знаком с тонкостями технологий строительного процесса. Почти скульптурная деталировка конструктивных элементов проекта - во многом его заслуга.

В пояснительной записке к конкурсному проекту нетрудно заметить почти буквальное повторение текстов этих манифестов. Роджерс и Пиано писали: «Мы уверены, что здания должны обладать способностью к изменению не только в плане, но также секциями и этажами. Свобода, предоставляемая людям в осуществлении их собственных намерений, организация пространства и масштаб являются следствием ясного понимания и предоставления возможности соответствовать процессам, для которых здание предназначено, а также следствием усовершенствования каждого его элемента, систем технологического оборудования и средств коммуникаций внутри выразительной и рациональной конструктивной системы. Эта система должна позволять людям ощущать себя одновременно внутри и снаружи, она должна изменяться и адаптироваться в соответствии с требованиями потребителя. Подобная демонстрация свободы и динамики становится образным выражением архитектуры, которая трактует здание в большей степени как гигантский механический набор, нежели статичное здание-монумент или прозрачный кукольный дом» [1, p. 237].

Для профессионалов в этом проекте явно прочитывалась основная идея модернизма - создание «здания-машины». В частности, прослеживались очевидные параллели с популярными в то время представлениями Седрика Прайса (идейного вдохновителя группы "Аркигрэм") об общественном комплексе будущего, воплотившиеся в известном проекте 1960 года - Дворце развлечений. Этот проект основывался на идее доступности культуры, науки и образования для каждого. Он предлагал утилитарную инженерную структуру, изменяющуюся нажатием кнопки под соответствующие требования эксплуатации, универсальную модульную конструкцию, которую можно легко собрать и разобрать. Это сооружение должно было стать своего рода «городской игрушкой», тем, с чем можно взаимодействовать, общаться и играть.

Если Дворец развлечений в безликих образах инженерных структур, всколыхнув умы молодёжи, так и остался футурологическим проектом, то Центр Помпиду можно считать первым сооружением, в котором реализовались все предложенные авторами идеи. Отличие, которое и сыграло решающую роль, заключалось в том, что, по мнению Роджерса, 
для выражения идей своего времени архитектура должна иметь соответствующий язык, выражать художественно осмысленное послание обществу. Его проекты походили больше на аркигрэмовские «Город подключающихся ячеек» Питера Кука и «Шагающий город» Рона Херрона (1964) с их фантастическими роботоподобными образами.

Основой концепции группы Роджерса, собравшейся для разработки конкурсного проекта (в работе группы также принимал участие итальянский архитектор Джанфранко Франчини), была идея создания демократичного, трансформируемого пространства, предоставляющего максимум свободы для различных видов деятельности и развлечений, а также обеспечивающего людей актуальной информацией в условиях «информационного общества» второй половины XX века. На фасаде здания планировали установить огромный экран, а в нижнем уровне - холл с множеством телевизоров, транслирующих программы разных стран мира. Во втором уровне предполагалось разместить информационный центр, на третьем - обширную библиотеку, а на верхних - киноконцертный зал и музейно-выставочное пространство. Площадь перед зданием виделась пространством для органичного продолжения деятельности, происходящей внутри здания.

Важную роль сыграло то обстоятельство, что стройке был придан исключительный статус. По особому распоряжению Жоржа Помпиду в процессе работ снимались все возникавшие проблемы и существовавшие ограничения - нормативные, технические и финансовые. Именно за счёт этого проект получил свою максимально полную реализацию.

Но было и несколько вещей, которые осуществить не удалось. С фасада пришлось убрать электронный экран из опасения властей его использования в целях политической пропаганды. Идеи «гибкости» и «подвижности» также были реализованы не полностью - не удалось осуществить предполагаемый проектом подвижный пол и возможность развития этажности вверх. Но на этажах, представляющих собой единое пространство, обеспечивалась свобода выделения зон трансформируемыми перегородками. Также пришлось отказаться от подвесных потолков, а технологическое оборудование превратилось в элементы декора интерьера. Это привычное сегодня решение тогда воспринималось как безумная смелость, тем более в интерьере общественного центра подобного уровня (рис. 2).

Объективная необходимость уменьшить высоту здания на четыре метра привела к исчезновению открытого корбюзеанского пространства на уровне земли, а Центр музыки пришлось выделить в отдельный объём и частично заглубить в землю, поскольку здание не должно было занимать собой весь отведённый участок. Необходимо было оставить место для площади, которая, по задумке авторов, должна была оставаться главной и органично перетекать в пространство здания.

В реализации проекта важную роль сыграло участие ещё одного представителя компании «0ве Аруп энд партнерс»
- талантливого инженера Питера Райса. Металлический каркас здания с его помощью был превращён в гигантскую скульптуру (рис. 3). Для перекрытия пролётов шириной 50 м он применил пионерские для того времени пространственные структуры с отливкой металлических крепёжных деталей по индивидуальным чертежам. Каждая стальная рама была собрана за десять дней из готовых элементов с помощью болтов и гаек прямо на строительной площад-

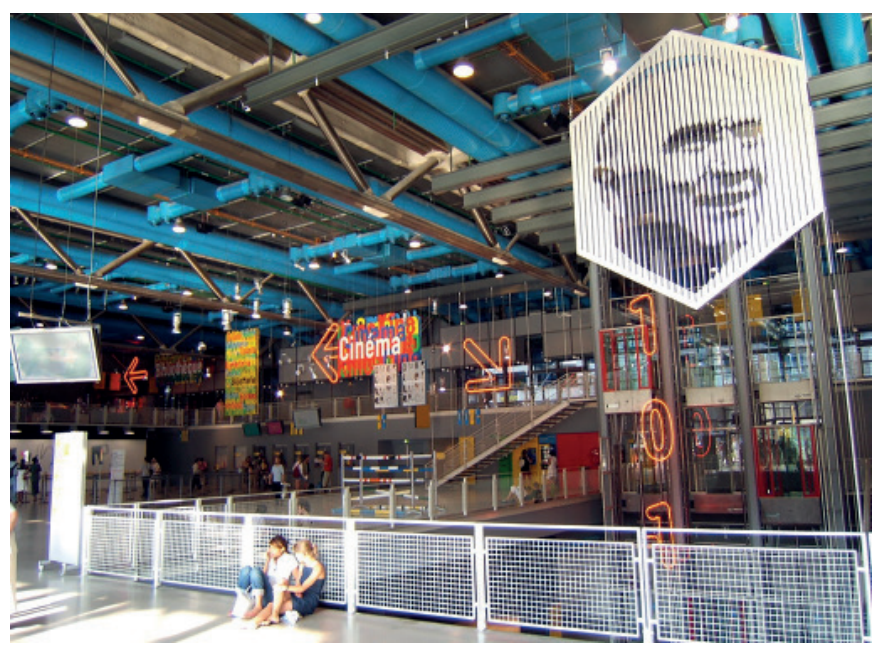

Рис. 2. Интерьер Центра Помпиду. Фото Брайана Педдингтона

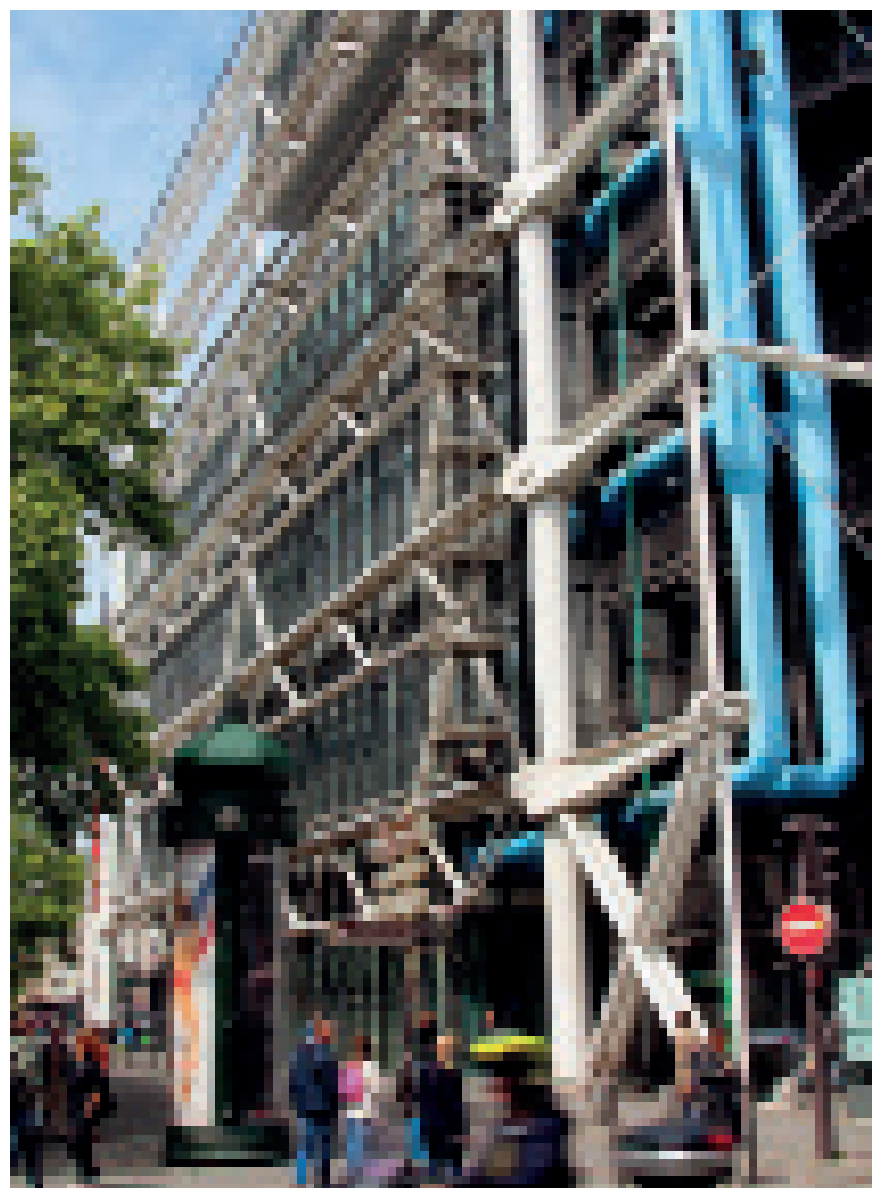

Рис. 3. Фрагмент фасада с гербереттами. Фото С. Плужник 
ке. В дополнение к основной несущей конструкции Райс сделал внешний металлический каркас для размещения вынесенного на фасад технологического оборудования. Рациональное распределение нагрузок, обеспечивалось оригинальной системой подвижных соединительных балок-гербереттов, которые и определили в конечном итоге весь облик здания. Изготовить их из особо прочной стали смогли лишь по специальному заказу на немецких заводах

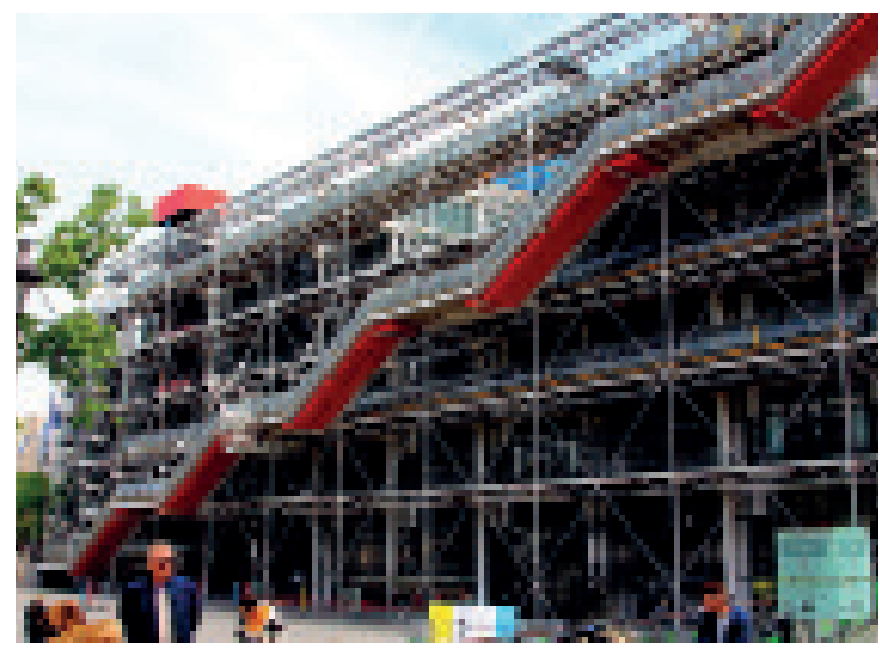

Рис. 4. Фасад со стороны площади с эскалаторами. Фото С. Плужник

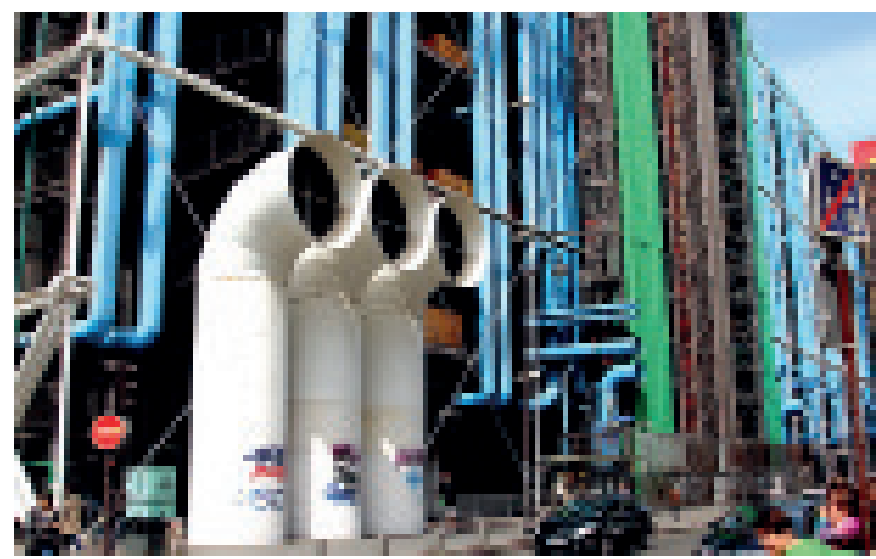

Рис. 5. Фасад со стороны улищы. Фото С. Плужник

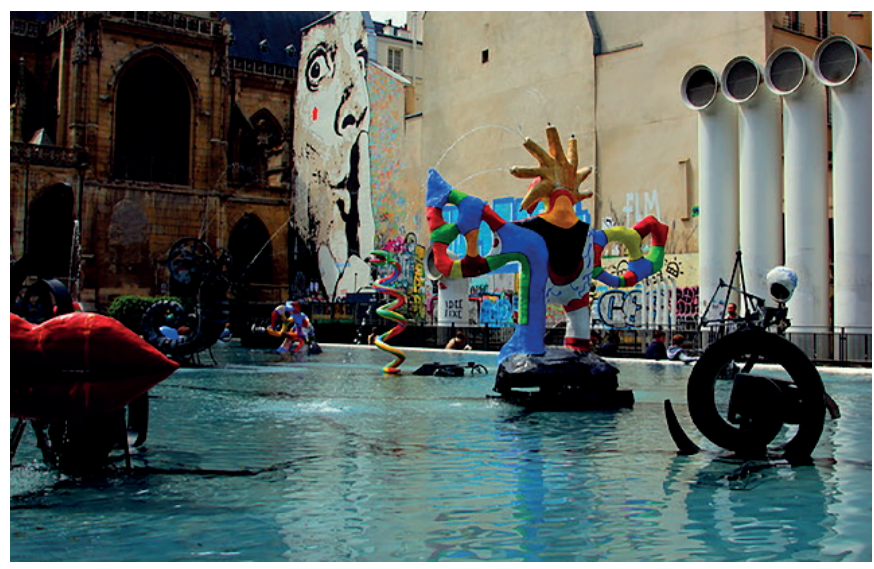

Рис. 6. Фонтан на площади Стравинского. Фото С. Плужник
Круппа, поскольку раньше литые детали подобных размеров в строительстве не использовались. Внешние концы герберетт соединялись прямоугольным каркасом из тяг и пересекающихся диагональных связей (рис. 4).

Эта сетка создала жёсткую конструкцию и за счёт строгой геометрии объединила весь хаос вынесенных на фасад элементов в единую законченную композицию. Эскалатор длиной в 150 м, подобно спасательным шлюпкам на корабле, подвесили внутри стеклянной армированной трубы к каркасу здания стальными тросами. Он как бы втягивал людей с улицы, приглашая в пространство здания.

В процессе разработки стальных опор каркаса, которые должны были оставаться открытыми, возникла проблема пожарной безопасности, поскольку традиционная облицовка бетоном стальных конструкций была не допустима из эстетических соображений. В результате была придумана противопожарная система, позволяющая мгновенно заливать основные колонны здания водой из расположенных на крыше гигантских кубов. Трубы сверху были оставлены открытыми, так что закипающая вода, выливаясь из них, предотвращала бы несущие колонны от деформации.

Хотя Пиано возражал против использования на фасаде обнажённой конструкции, Роджерс был уверен, что скульптурный характер разработанных ими стальных узлов способен сообщить зданию достойное эстетическое качество.

Кроме того, вынесенные на фасад все технологические системы жизнеобеспечения и коммуникационные системы, лестницы и лифты, были мастерски превращены в своеобразный архитектурный декор, усиленный по выразительности окраской в цвета французского флага - красный, синий, белый, кое-где дополненные жёлтым и зелёным (рис. 5).

Такой приём обеспечивал свободную планировку здания и упрощал ремонт и замену оборудования в случае их износа и морального устаревания.

В итоге здание получило конструктивно обоснованный и художественно выразительный образ гигантской стальной скульптуры. Он вступал в конфликт лишь с привычными образами гражданской архитектуры, но был вполне сопоставим с популярными кинетическими скульптурами и метамеханикой таких известных и признанных художников, как Габо, Каро и Тэнгли. Произведения последнего, как подтверждение единства взглядов на присутствие индустриальных мотивов в современной культуре, были установлены на смотровой площадке Центра Помпиду и в фонтане на прилегающей к зданию площади Стравинского (рис. 6). Интересно, что в конце 1990-х скульптор Энтони Каро был приглашён Норманом Фостером для участия в проектировании пешеходного моста Миллениум в Лондоне.

С лёгкой руки журналистов Центр Помпиду окрестили провозвестником нового стиля хай-тек в архитектуре, хотя в этом сооружении с трудом можно найти использование «высоких технологий». Весь пафос работы его авторов был действительно нацелен на привлечение передовых 
технологических разработок из опережающих областей техники, однако они никак не могли согласиться с ярлыком «стиль хай-тек», приклеиваемым к их сооружениям. Внешние механоморфные черты отражали лишь попытку найти новый архитектурный язык, который, вместе с нивелированием черт самой техники нового поколения, скоро сошёл на нет, оставив в наследство дизайну свой имидж «преуспеяния». В какой-то мере появление Центра Помпиду было связано с общим духом неудовлетворённости состоянием современной архитектуры и популярностью идей постмодернизма. Вместе с тем в своих работах Ричард Роджерс всегда настаивает на том, что всё его творчество - это продолжение и развитие ещё недостаточно освоенного слоя внутри основной линии Современного движения.

За время своего существования Центр Помпиду стал действительно самым общедоступным и посещаемым местом Парижа. С эскалатора и верхних террас его открываются прекрасные панорамы города. В залах Центра Помпиду было проведено множество интереснейших выставок, а коллекция музея значительно выросла и стала мировым лидером в области современного искусства. По словам критика Кеннета Павелла, «Центр Помпиду стал первой в мире вертикальной площадью с улицами в воздухе, террасами, лифтами и эскалаторами» [2, р. 15]. Это действительно архитектура вовлечения и соучастия для людей всех возрастов, верований и интересов, способная к адаптации и множественному использованию. «Центр Помпиду стал «мозгами» французской столицы - местом для чтения, обсуждений, прослушивания музыки, просмотра фильмов, картин и скульптур. Это здание изменило характер депрессивного района Парижа и декларирует фундаментальную веру Роджерса в то, что город может приспосабливаться под запросы людей» [3, p. 44].

Вместе с тем неудачным решением для здания подобного назначения можно считать потерю почти половины объёма за счёт значительных межферменных пространств. Возможно, стремление перекрыть 50-метровые пролёты в данном случае было избыточным. Также определённые проблемы возникли в помещениях со сплошными наружными витражами при организации экспозиций, которые требовали дополнительных глухих плоскостей.

В 1992 году была проведена реорганизация комплекса с целью создания отдела культурного развития, который должен был заниматься проведением живых выступлений, кинопоказов, лекций, симпозиумов и различных дискуссий. Предусмотренная проектом возможность трансформации рабочих пространств внутри существующей конструкции позволила это сделать, а также объединить Музей современного искусства и Центр промышленного дизайна.

После двадцати лет функционирования центра правительством были выделены средства на ремонтные работы с обновлением лифтовых блоков. Они длились два года: с 1997-го по 1999-й, а в 2000-2004-м годах были проведены работы по расширению экспозиционного пространства галереи почти до ста тысяч квадратных метров площади. И эта возможность также была предусмотрена в проекте (рис. 7).

На 2018-2020 годы намечены новые работы по реновации: замена наружных эскалаторов на фасаде. При этом в процессе проводимых работ сооружение будет оставаться доступным для посетителей.

Центр Помпиду успешно функционирует, подтверждая жизнеспособность целого ряда прогрессивных идей. Однако очевидно, что в случае реконструкции технологического оборудования, когда отпадёт необходимость в использовании того или иного его элемента, существующая композиция, представляющая собой единый арт-объект, останется первозданной и нарушаться не будет. Вопреки заложенным в проект декларациям сегодня Центр Помпиду воспринимается как застывший функциональный монумент, отменивший собственный тезис о временности и встроенной подвижности, подтверждая убеждённость Седрика Прайса, к которой он пришёл к концу своей жизни, в «медлительности и неповоротливости» архитектуры.

Главная заслуга Центра Помпиду - это легитимизация совершенно нового типа архитектурного сооружения, соответствующего идейным устремлениям и передовым технологическим возможностям своего времени. По существу он стал одним из немногих овеществленных манифестов профессиональных концепций современной архитектуры. Появление такого масштабного, шокирующего своим обликом сооружения придало профессии мощный импульс, открыло новые горизонты профессиональных возможностей и представлений, стимулировало рождение самых невероятных творческих замыслов, осуществлению которых способствовала бурно развивающаяся техника уже нового поколения рубежа веков.

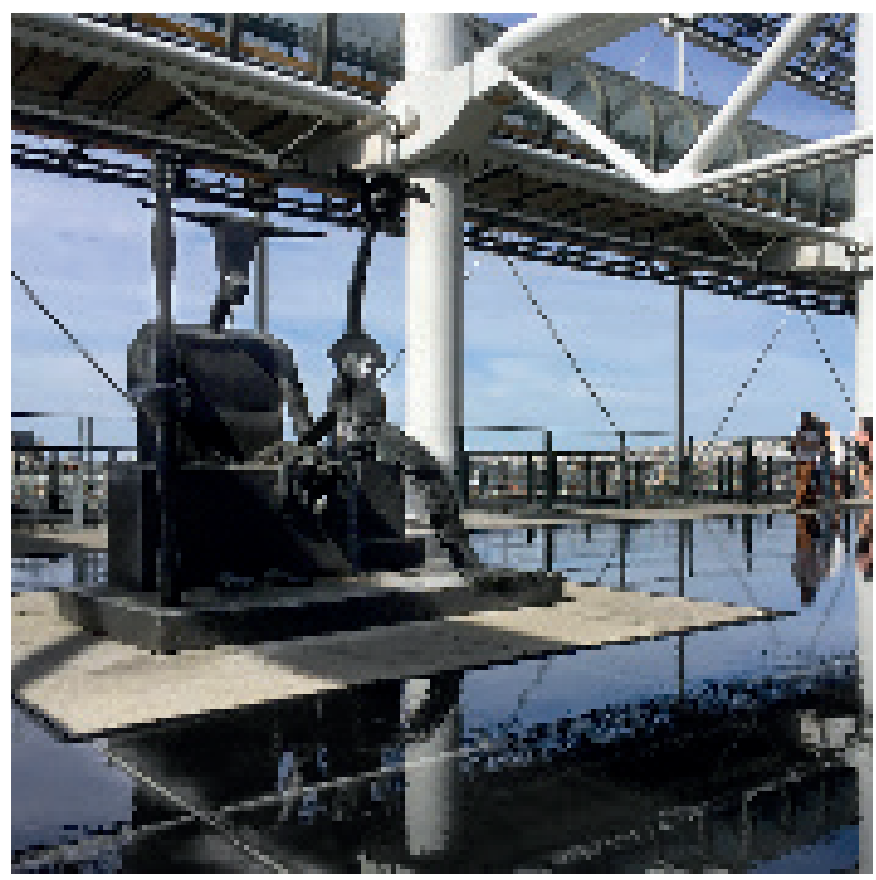

Рис. 7. Экспозиция скульптур на открытых террасах. Фото Юкка 


\section{Лumepamypa}

1. Architecture Document. Special Issue. 1970-1980. Tokio, 1980. - P. 237.

2. Powell, K. Architecture of the future / K. Powell. - BaselBoston-Berlin. - 2002.

3. Powell, K. Richard Rogers / K. Powell. - Zurich-MunchenLondon, 1994. - P. 44-52.

4. Powell, K. Architecture of the future. Richard Rogers / K. Powell; Edited by R. Torday. - Bazel- Boston-Berlin : Birkhäuser, 2006. - P.15-17.

5. Rogers $R$. Cities for a small planet / R. Rogers, P. Gumuchdjian. - London : Faber and Faber. - 1997. - P. 76-79.

6. Rogers, R. Architecture. A modern view / Rogers R. London, Thames and Hudson, 1990.

7. Buchanen, P. High-Tech. Another British thoroughbred / P. Buchanen // The Architectural Review. - 1983. - № 1037. -P. 28.

8. Davies, C. Le High-Tech. N'Estil QU'UN style? / C. Davies // L'Architecture d'Aujourd'hui . -1985. - № 237. - P. 42-46.

9. Pelissier, A. Entrettien avec Richard Rogers / A. Pelissier // Technique Architecture. - 1983. - № 350. - P. 81.

10. Richard Rogers // RIBA Journal. - 1977. - № 1. - P. 11.

11. Гершкович, Е. Центр Помпиду отмечает сорокалетний юбилей [Электронный ресурс] / Е. Гершкович // Art and Houses. - Режим доступа: http://art-and-houses. ru/2017/02/03/sorokoletnij-yubilej-otmechaet-tsentrpompidu-v-parizhe/ (дата обращения 19.08.2019).

\section{References}

1. Architecture Document. Special Issue. 1970-1980. Tokio, 1980. (In Engl.)

2. Powell K. Architecture of the future. Basel-Boston-Berlin, 2002. (In Engl.)

3. Powell K. Richard Rogers. Zurich-Munchen-London, 1994, pp. 44-52. (In Engl.)

4. Powell R. Architecture of the future. In R. Torday (ed.) Richard Rogers. Bazel- Boston-Berlin, Birkhäuser Publ., 2006, pp. 15-17. (In Engl.)

5. Rogers R., Gumuchdjian P. Cities for a small planet. London, Faber and Faber Publ., 1997, pp. 76-79. (In Engl.)

6. Rogers R. Architecture. A modern view. London, Thames and Hudson Publ., 1990.

7. Buchanen P. High-Tech. Another British thoroughbred. The Architectural Review, 1983, no. 1037, p. 28.

8. Davies C. Le High-Tech. N'Estil QU'UN style? L'Architecture d'Aujourd'hui, 1985, no. 237, pp. 42-46. (In Franc.)

9. Pelissier A. Entrettien avec Richard Rogers. Technique Architecture, 1983, no. 350, p. 81. (In Franc.)

10. Richard Rogers. RIBA Journal, 1977, no. 1, p. 11.

11. Gershkovich E. Tsentr Pompidu otmechaet sorokaletnii yubilei [Elektronnyj resurs] [Pompidou Center celebrates its 40th anniversary]. Art and Houses. URL: http://art-andhouses.ru/2017/02/03/sorokoletnij-yubilej-otmechaet-tsentrpompidu-v-parizhe/ (accessed 19.08.2019). (In Russ.)

Возвышаева Татьяна Ивановна (Москва). Кандидат архитектуры. Ведущий научный сотрудник Научно-исследовательского института теории и истории архитектуры и градостроительства (филиал ФГБУ «ЦНИИП Минстроя России») (111024, Москва, ул. Душинская, 9. НИИТИАГ). Эл. почта: t.vozvyshaeva@gmail.com.

Vozvyshaeva Tatyana Ivanovna (Moscow). Candidate of Architecture. Leading researcher at the Research Institute of Theory and History of Architecture and Urban Planning (9 Dushinskaya st, Moscow, 111024. NIITIAG), branch of the Central Institute for Research and Design of the Ministry of Construction and Housing and Communal Services of the Russian Federation (TsNIIP). Email: t.vozvyshaeva@gmail.com. 